ノ 一 ト

\title{
${ }^{99 m}$ Tc-sulfur colloid による肝シンチグラフィ
}

\author{
西川秀人, 児玉 求 \\ 広島大学医学部第二外科 \\ 1971年 7 月 7 日 受理
}

\section{緒言}

肝スキャンは1953年 Stirret らにより原理的に確立 され1), 肝スキャン用放射性医薬品としては, 今日 ${ }^{131} \mathrm{I}$ 標識ローズベンガル打よび ${ }^{198} \mathrm{Au}$-colloid がもっとも 広く使用されている。1964年 Harper らにより ${ }^{99 m} \mathrm{Tc}$ が紹介され22, その有用性が述べられ帛， ${ }^{99 m} \mathrm{Tc}$-sulfur colloid による肝, 脾のシンチグラフィが報告され行 なわれるようになっだ22 55,8),9)。われわれは1970年 9 月以来, ${ }^{198} \mathrm{Au}$-colloid の代的りに ${ }^{99 m} \mathrm{Tc}^{-}$-sulfur colloid よる肝シンチグラフィを正常15例を含む 30 例に 行なったので報告する。

\section{${ }^{99 m}$ Tc-sulfur colloid の作製}

${ }^{99 m} \mathrm{~T}$ c-sulfur colloid の作製は, Mallinckrodt 社 製 Ultra Technekow（第一ラジオアイソトープ研究 所提供）より生食水で無菌的にミルキングした。

${ }^{89 \mathrm{~m}} \mathrm{TcO}_{4}^{-} 5 \mathrm{~m} l$ を $20 \mathrm{~m} l$ の隇菌バイアルビンにとり, A 試薬 $\left(\mathrm{Na}_{2} \mathrm{~S}_{2} \mathrm{O}_{3} \cdot 5 \mathrm{H}_{2} \mathrm{O} 2.08 \mathrm{mg} / \mathrm{ml}, \mathrm{KH}_{2} \mathrm{PO}_{4} 25.5\right.$ $\mathrm{mg} / \mathrm{m} l$, EDTA・2 Na $2.79 \mathrm{mg} / \mathrm{m} l)$ およびB試薬 $(0.5$ $N-\mathrm{HCl}$ )を順次無菌的に加えてよく振とうする。つい で沸とう水浴中 $\left(95 \pm 3^{\circ} \mathrm{C}\right)$ で正確に 10 分間加熱する。室 温にて 5 分間放置したのち, C試薬 $\left(\mathrm{NaH}_{2} \mathrm{PO}_{4} \cdot 2 \mathrm{H}_{2} \mathrm{O}\right.$ $70 \mathrm{mg} / \mathrm{ml}, \mathrm{NaOH} 36 \mathrm{mg} / \mathrm{ml}$ ) を無菌的に加光振とう し，さらにD試薬 (10\% mannitol)を加光良く振とう する。ふたたび沸とう水浴中 $\left(95 \pm 3^{\circ} \mathrm{C}\right)$ に 2,3 分間加 熱し．室温にて放冷後使用した。

\section{方 法}

使用した装置は Nuclear Chicago 社製, Pho/Gamma III シンチカメラを用い,コリメーターは 4,000 hole を使用した。患者は仰臥位とし, ${ }^{99 m} \mathrm{Tc}$-sulfur colloid $3 \sim 5 \mathrm{mCi}$ 静注投与後15〜30分に肝シンチ> ォトを作成した。 ${ }^{99 m} \mathrm{Tc}$-sulfur colloid $3 \sim 5 \mathrm{mCi}$ 投 与で, 大部分の症例は 30 秒以内で肝ンンチフォトを得 ることができ，呼吸停止下肝シンチグラフィが可能で
ある(6),10)。

\section{症例および結果}

症例は, 正常 15 例，急性拈よび慢性肝炎 7 例，転移 性肝がん 4 例, 原発性肝がん 2 例, 白血病 2 例の計 30 例である。以下症例を示す。

症例 1 51才 우

正常例の平常呼吸時㧍よび呼吸停止下肝シンチフォ トを示す(Fig. 1)。

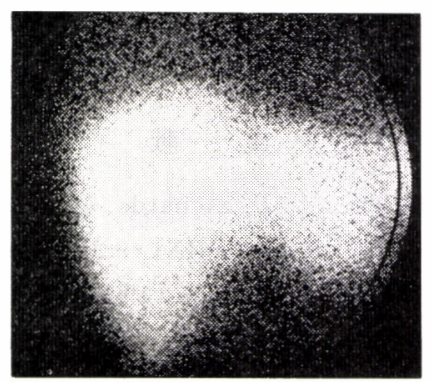

Normal respiration

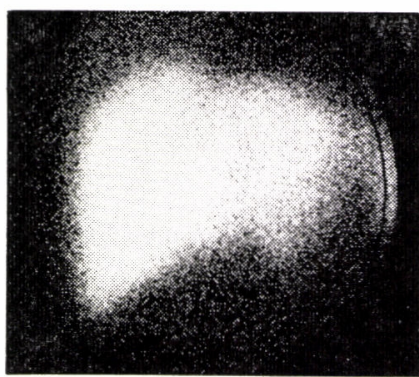

Suspended respiration

Fig. 1 51Y 우 Normal case.

呼吸停止下肝シンチフォトにて, 従来呼吸性移動の ため読影困難であった横隔膜穹隆部, 肝下縁の状態を より鮮明に描画することが可能で，肝はより本来の形

$\dagger$ Liver Scintigraphy with ${ }^{99 m} \mathrm{Tc}$-Sulfur Colloid, Hideto NishiKawa, Motomu Kodama: 2nd Department of Surgery, School of Medicine, Hiroshima University, Hiroshima-shi 
態を示す。また, 正常 15 例中 12 例に脾の出現を認め た。

症例 2,56 才, 우

胃がん患者で, 開腹手術時脾腫大を伴った慢性肝炎 を認めた症例で，肝ンンチフォトとともに腫大した脾 を明らかに描画することにより脾の大きさを知ること か゚できる(Fig. 2)。

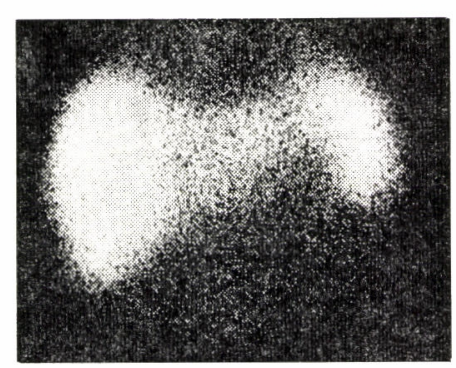

Fig. 2 56 Y 우

Chronic hepatitis with splenomegaly.

症例 3,46 才, 古

左葉の原発性肝がんで, 左葉切除術を行なった症例 で, 左葉に限局した space occupying lesion (SOL) と右葉の代償性腫大を認める（Fig. 3)。

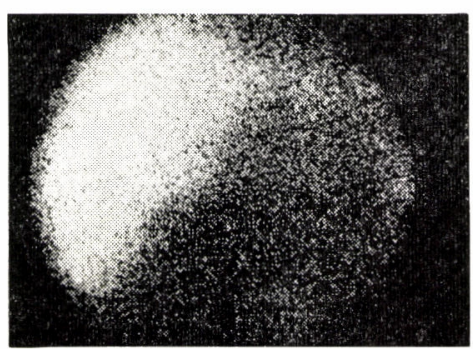

Fig. $346 \mathrm{Y}$ 占

Primary hepatic cancer left lobe.

症例 4,73 才, 今

胃がん術後の患者で, 肝は全般的に腫大し, 集積が 不良で薄く描画されるも，多発性の欠損像を認め，多 発性転移性肝がん像を示す(Fig. 4)。

\section{考察}

${ }^{99 m} \mathrm{~T}$ c は $140 \mathrm{keV}$ の単一 $\gamma$ 線を放出して崩壊し, collimation が良く, その半減期は 6 時間で, 低い照 射線量で大量投与が可能である ${ }^{4)}$ 。したがって高い計 数率を得ることにより，RI の集積が不良な病変肝に 抢いても計数率の低下によるシンチグラム像のむらを

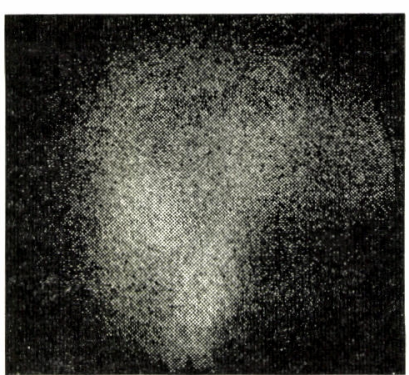

Fig. 4 73Y ô

Metastatic hepatic cancer (multiple).

防ぐことができる。さらに従来, 肝シンチグラムに物 いて呼吸性移動に上る肝辺縁像の歪及や解像力の低下 が問題になっていたが6), シンチカメラと ${ }^{99 m} \mathrm{Tc}$-sulfur colloid の使用により呼吸停止下に肝ンンチフォトを 得ることが可能となり, 肝辺縁像をより鮮鋭にとら古 ることができ, SOL の検出能の向上にも役立つもの と思われる。金子らは欠損像の内腔の状態より質的診 断の可能性について述べている10)。, 撮影時間が 短くてすみ, 短時間で多方向撮影を行ならことにより 診断能の向上が得られる。脾㵴の出現については, わ れわれは正常15例中12例に脾影の出現を認め, ${ }^{199} \mathrm{Au}$ colloid に上る肝硬変症あるいは門脈圧方進時に見 られる脾臓の出現とは意味が異なるものと考光られ る $^{13)}$ 。

Petasnick は ${ }^{99 m} \mathrm{~T} \mathrm{c}^{-}$-sulfur colloid が脾シンチグ ラフィに有意義であると述べて抢り》，同時に肝，脾 シンチグラフィを得ることにより肝/脾比 ${ }^{12), 13)}$ ， ある いは脾の大きさを測定した報告もみられ 討を要するところである。

\section{結語}

${ }^{99 m} \mathrm{~T} \mathrm{c}$-sulfur colloid による肝シンチフォトを作成 し，その有用性について検討した。

本論文の要旨は第 6 回日本核医学会中四国部会飞拧 いて発表した。

\section{文献}

1) Stirret, L.A., Yuhl, E.T. and Libby, R.L.: Radiology, 61, 930 (1953)

2) Harper, P.V., Beck, R., Charieston, D. and Lathrop, K.A.: Nucleonics, 22, 50 (1964)

3) Harper, P.V., Lathrop, K.A., Jiminez, F., Fink, R. and Gottschalk, A.: Radiology, 
85, 101 (1965)

4) Smith, E.M.: J. Nucl. Med., 6, 231(1965)

5) Gottschalk, A.: Am. J. Roentgen., 97, 860 (1966)

6) Gottschalk, A., Harper,P.V., Jiminez, F. and Petasnick, J.P.: J. Nucl. Med., 7, 243 (1966)

7) Petasnick, J.P., et al.: J. Nucl. Med., 7, 733 (1966)
8) Leonard, M.F. and Richard, A.R.: New York State J. Med., 67, 271 (1967)

9) Gottschalk, A.: JAMA, 200, 630 (1967)

10）金子, 他: Radioisotopes, 19, 597 (1970)

11) Richard, M.S., David, V.B. and James, R. H.: J. Nucl. Med., 11, 689 (1970)

12) Bekerman, C. and Gottschalk, A.: J. Nucl. Med., 12, 237 (1971)

13）岩崎, 他: 核医学, 8,12 (1971) 